\title{
HUBUNGAN GAYA KEPEMIMPINAN DAN SISTEM PENGENDALIAN MANAJEMEN TERHADAP TERBENTUKNYA BUDAYA DI PERUSAHAAN KELUARGA DEVELOPER “ $X$ ”
}

\author{
Olinda Lestari \\ Jurusan Akuntansi/ Fakultas Bisnis dan Ekonomika \\ lindahartanto56@yahoo.com
}

\begin{abstract}
Abstrak - Penelitian ini merupakan penelitian basic research yang bertujuan untuk meningkatkan pemahaman mengenai hubungan gaya kepemimpinan dan sistem pengendalian manajemen terhadap terbentuknya budaya di perusahaan keluarga PT. X. Penelitian ini menggunakan pendekatan kualitatif dengan metode pengumpulan data yaitu wawancara, observasi dan analisis dokumen. Hasil penelitian ini menunjukkan bahwa gaya kepemimpinan dan penerapan sistem pengendalian manajemen memiliki hubungan yang saling mempengaruhi terhadap terbentuknya budaya perusahaan. Gaya kepemimpinan seorang pemimpin dipengaruhi oleh nilai budaya keluarganya yang telah melekat dalam dirinya, dimana sistem pengendalian manajemen yang diterapkan disertai dengan nilai-nilai tersebut, sehingga kemudian akan menjadi dasar dari perilaku seluruh anggota organisasi. Faktor yang membentuk budaya tidak hanya dari kepemimpinan saja, tetapi melalui ikatan emosional yang tercipta antara pemimpin dan karyawan akan menciptakan pengendalian budaya yang efektif dalam mendukung terbentuknya budaya yang baik. Oleh karena itu budaya organisasi yang kuat merupakan komponen dari pengendalian yang juga membentuk adanya pengendalian budaya yang efektif untuk mengendalikan tindakan karyawan agar sesuai dengan budaya organisasi yang ada.

Kata Kunci: Gaya kepemimpinan, Sistem pengendalian manajemen, Budaya organisasi, Perusahaan keluarga
\end{abstract}

Abstract - This study is basic research that aims to improve the understanding of the relationship leadership style and management control system against formation culture in a family enterprises PT. X. This study used a qualitative approach with method of data collection are interviews, observation and document analysis. These results indicate that the style of leadership and the implementation of management control systems have a relationship of mutual influence on the formation of the corporate culture. The leadership style of a leader is influenced by his family cultural values that have been inherent in her, where management control systems are implemented along with these values, which then will be the basis of the behavior of all members of the organization. Factors that shape the culture not only of leadership, but through the emotional bond created between leaders and employees will create effective cultural control in supporting the formation of a good culture. Therefore, a strong organizational culture is a component of the control that is also shaping the effective cultural control to control the actions of employees to fit the existing organizational culture. 


\section{PENDAHULUAN}

Kelangsungan dan tantangan bisnis keluarga (family business) menjadi salah satu isu menarik, tidak hanya di dalam negeri tetapi juga pebisnis global. Hasil survei Pricewaterhouse Coopers $(\mathrm{PwC})$ yang melibatkan 2.378 pebisnis di 40 negara menyuguhkan temuan menarik. Temuan dari survei itu di antaranya, pertama bisnis keluarga di Indonesia semakin kuat dan tumbuh lebih tinggi dari rata-rata dunia, dimana dengan adanya persaingan ketat dan regulasi pemerintah maka menjadikan bisnis lebih profesional dan perencanaan pewarisan usaha dianggap sebagai hal penting (koran.bisnis, 23 Desember 2014).

Dengan bertumbuhnya bisnis keluarga di Indonesia, maka setiap perusahaan keluarga perlu mengembangkan inovasi dan profesionalisme operasi bisnisnya dalam mengahadapi persaingan yang kian ketat. Oleh karena itu dalam badan usaha tak terkecuali perusahaan keluarga pasti membutuhkan dua hal penting dalam memajukan perusahaannya yaitu pemimpin dan karyawan. Pemimpin menetukan tujuan yang ingin dicapai oleh perusahaan secara bersama-sama yang dapat menjamin keberlanjutan dan perubahan yang ada dalam perusahaan keluarga, sedangkan karyawan merupakan aset beharga bagi organisasi dalam mendukung tercapainya tujuan perusahaan.

Perusahaan perlu mempersiapkan dan merencanakan alih kepemimpinan baru yang profesional baik dari kalangan keluarga maupun non-keluarga untuk tetap menjaga nilai-nilai yang ada. Labuan International Business and Financial Centre (Labuan IBFC) meluncurkan laporan riset baru yang menunjukkan bahwa usaha berbasis keluarga di Indonesia menempati posisi terdepan di Asia Tenggara dalam perencanaan dan persiapan alih kepemimpinan atau suksesi kepemimpinan setelah pemimpin sebelum mereka pensiun atau mundur Indonesia menempati posisi teratas dengan $78 \%$. Hanya $16 \%$ dari perusahaan Indonesia yang tidak memiliki rencana suksesi usaha (SWA, 29 Januari 2015).

Maka, pemimpin sebelumnya harus bisa mengkomunikasikan visi, misi, dan strategi perusahaan dengan jelas supaya setiap anggota baik yang keluarga maupun non-keluarga dapat memahami apa yang menjadi tujuan perusahaan. 
Disisi lain pemimpin juga harus memberdayakan karyawan, sehingga dapat tercipta budaya organisasi yang produktif bagi karyawan.

Menurut Giritli et al (2013), ada hubungan yang signifikan antara praktek kepemimpinan tertentu dan profil budaya tertentu dalam sektor konstruksi. Kedua gaya kepemimpinan paternalistik dan konsultatif ditemukan di lingkungan fleksibel dari klan budaya, manajer di perusahaan tersebut menggunakan beragam gaya kepemimpinan dalam fase yang berbeda atau menggabungkan unsur-unsur gaya yang berbeda dalam menanggapi lingkungan yang sangat kompleks dan turbulen di mana mereka bekerja. Namun penelitian tersebut tidak dalam konteks bisnis keluarga serta belum mengkaitkan dengan sistem pengendalian manajemen yang diterapkan oleh pemimpin dalam organisasi tersebut.

Menurut Efferin dan Hartono (2015), pe milik bisnis bukan pencipta budaya perusahaan melainkan mengadopsi budaya yang telah ada. Kepemimpinan merupakan faktor penting dalam desain dan implementasi sistem pengendalian manajemen. Dimana budaya masyarakat pusat dari sistem pengendalian manajemen. Sehingga dibutuhkan penelitian lebih lanjut untuk memahami bagaimana hubungan dari gaya kepemimpinan dan penerapan SPM dalam terbentuknya budaya kerja anggota organisasi di perusahaan keluarga dimana pemimpin tidak hanya mengadopsi budaya yang ada, tetapi juga berperan dalam mempengaruhi budaya organisasi.

\section{METODE PENELITIAN}

Penelitian ini termasuk penelitian kualitatif deskriptif (descriptive) karena bertujuan memberikan gambaran tentang hubungan gaya kepemimpinan dan penerapan sistem pengendalian manajemen di perusahaan keluarga. Metode pengumpulan data menggunakan wawancara, observasi, dan analisis dokumen. Wawancara dilakukan dengan menggunakan metode semi-structured dengan cara tatap muka secara langsung. Wawancara menggunakan media catatan tertulis, dilakukan pada pihak-pihak yang dianggap dapat memberikan data dan 
informasi dalam membantu peneliti menjawab research question yang ada. Penulis juga melakukan obeservasi secara non-participant dan dilakukan pada saat jam kerja perusahaan yang dilakukan pada bulan September 2015. Selain itu, penulis juga melakukan analisis dokumen yang berguna untuk memberi tambahan informasi yang kemudian dapat diverifikasi dengan hasil penelitian yang dilakukan.

\section{HASIL DAN PEMBAHASAN}

\section{Gambaran Umum Badan Usaha}

PT. X berdiri pada tahun 1999 di Surabaya, yang pada saat itu masih memiliki 7 orang karyawan. PT. X merupakan badan usaha yang bergerak di bidang real estate yang menawarkan jasa pembangunan perumahan yang dilengkapi dengan fasilitas umum dan sosial serta prasarana lingkungan yang menunjang kebutuhan penghuni perumahan. Perusahaan ini didirikan oleh Bapak K dan Bapak S dimana mereka berdua adalah saudara sepupu. Bapak K tertarik berusaha di bidang real estate, setelah Bapak $\mathrm{K}$ memperoleh keuntungan penjualan tanah yang lumayan besar dengan bantuan Bapak S. Perusahaan yang didirikan bersama tersebut dipercayakan kepada Bapak S.

Tanggung jawab untuk memimpin dan menjalankan kegiatan operasional perusahaan diserahkan kepada istrinya, yang mana istri Bapak S menjabat sebagai Direktur Utama. Sedangkan Bapak K dan Bapak S sebagai komisaris mengawasi dan mengevaluasi perkembangan perusahaan secara berkala melalui Ibu S.

\section{Nilai-nilai Budaya Keluarga Pemilik PT. X}

1. Kedisiplinan

Ibu S terbiasa disiplin sejak kecil sehingga hal tersebut juga dia terapkan dalam cara dia mendidik anaknya. Hal ini bertujuan agar anaknya bisa belajar disiplin dengan mengutamakan mana yang boleh dilakukan dan mana yang tidak boleh dilakukan. Melalui pengajaran displin yang 
konsisten, mereka akan lebih terbiasa untuk hidup lebih tertib tidak hanya di lingkungan keluarga, namun juga saat berada di luar lingkungan keluarga.

2. Berbagi Peran

Pembagian tugas dalam keluarga tidak hanya Ibu S dan Bapak S saja, tetapi anak-anak juga dilibatkan. Hal ini bertujuan agar semua anggota keluarga turut bertanggung jawab terhadap pekerjaan rumah tangga sebagai proses dalam membangun kepribadian yang lebih mandiri dan bertanggung jawab terhadap setiap tugas-tugasnya hingga selesai. Selain itu, pengajaran tersebut juga akan melekat dalam diri seseorang, sehingga akan memudahkan dalam menyesuaikan diri ketika berada di luar lingkungan keluarga.

3. Kerapian dan kerajinan

Ibu $\mathrm{S}$ juga membiasakan keluarganya untuk menjaga kerapian. Hal ini dibiasakan dengan memulai dari hal-hal kecil seperti meletakkan barangbarang perabot rumah tangga pada tempatnya setelah digunakan. Selain itu Ibu S juga mengajarkan kepada keluarganya untuk selalu rajin bekerja, beribadah, serta rajin bangun pagi untuk berolahraga. Yang mana hal tersebut juga sebagai proses membentuk karakter yang rajin dalam melakukan suatu pekerjaan, serta sebagai latihan untuk membiasakan diri dengan rutinitas-rutinitas yang ada.

4. Kepedulian

Dalam mengatur keluarganya, Ibu S selalu menekankan pada anak-anakanya untuk selalu menghargai orang lain meskipun berbeda keyakinan dan berteman dengan siapa saja tanpa membeda-bedakan latar belakang seseorang. Melalui pengajaran nilai kepedulian ini, mereka akan terlatih untuk menjaga hubungan antar sesama dengan erat.

5. Kebersamaan

Kebersamaan dalam keluarga dilakukan dengan selalu sarapan pagi bersama, pergi berwisata bersama, menjalankan ibadah bersama dan membantu mengajari anak menyelesaikan tugas sekolahnya. Melalui 
kegiatan-kegiatan kebersamaan dan komunikasi yang selalu terjaga, maka dalam keluarga akan tercipta hubungan yang harmonis serta hubungan emosional tetap terjalin satu dengan yang lainnya.

6. Kesabaran

Ibu S dalam mengatur keluarganya selalu menekankan nilai kesabaran. Ketika Bapak S menghadapi masalah pekerjaan di lapangan, Ibu S memberikan dukungan selalu menasehati Bapak $\mathrm{S}$ untuk sabar dan tetap rajin beribadah serta berdiskusi bersama mencari solusi terbaik dari masalah tersebut. Melalui hal tersebut keluarganya akan belajar untuk tidak mudah putus asa dan lebih bijaksana dalam menghadapi masalah serta belajar untuk terus mengembangkan kemampuan yang dimilikinya.

\section{Gaya Kepemimpinan yang diterapkan dalam PT. X}

Gaya kepemimpinan yang diterapkan Ibu $\mathrm{S}$ kombinasi antara transformational dan transaksional. Ibu S merupakan sosok yang terbuka, diluar jam kerja Ibu $\mathrm{S}$ berbincang-bincang dengan karyawannya sambil bercanda tawa menanyakan kabar karyawannya baik tentang pekerjaan maupun masalah keluarga. Dengan menunjukkan sikap saling pengertian akan menumbuhkan ikatan emosional antara pemimpin dan karyawan. Dia mendorong karyawannya untuk belajar menjadi pribadi yang tangguh dan mandiri dengan memberikan kepercayaan kepada karyawannya untuk mengambil keputusan terkait dengan tugas dan tanggung jawabnya masingmasing, namun tetap tanpa mengabaikan ketentuan perusahaan yang telah ada.

Ibu S juga tak segan-segan membagikan pengalamannya selama bekerja kepada para karyawannya supaya mereka dapat memetik apa yang baik yang perlu diterapkan dalam pekerjaannya. Selain itu, setiap saran dan kritik dari karyawan juga selalu didengarkan, bahkan juga menjadi pertimbangan ketika Ibu S akan mengambil keputusan. Dalam bekerja, Ibu S selalu menekankan ketelitian dan kerapian pada setiap pembuatan laporan, dimana semua laporan 
yang diminta olehnya harus disajikan secara sistematis, namun tetap mengena pada penyampaian hasil laporan tersebut.

Dalam memberikan pengarahan tugas, Ibu $\mathrm{S}$ mengkomunikasikan terlebih dahulu pada karyawannya terkait perintah dan tugas khusus yang diberikan, serta sebelumnya disesuaikan dengan kemampuan dan keahlian dari karyawannya. Dari tugas yang diberikan oleh Ibu S, dia akan menilai kinerja karyawannya untuk mengetahui bagaimana kemampuan mereka dalam menyelesaikan tugas-tugasnya, hal ini juga berguna untuk melihat kelayakan karyawan tersebut atas posisi yang ditempatinya. Dalam menjalankan kepemimpinannya di perusahaan, Ibu S memberikan perhatian yang sama pada seluruh karyawannya tanpa memandang adanya hubungan kekeluargaan. Bekerja secara professional ditunjukkan Ibu S dengan memperlakukan semua karyawannya secara adil karena itu bukan sekedar tanggung jawab moral, namun hal itu diperlukan untuk pertumbuhan perusahaan.

Setiap peraturan perusahaan dijalankan disiplin, dimana jika karyawan melakukan kesalahan tentu ada konsekuensinya seperti pemberian sanksi. Ibu S selalu menegur mereka secara pribadi dan memberikan peringatan agar mereka menyadari kesalahannya dan tidak mengulangi lagi. Namun bila karyawan tersebut terus melakukan kesalahan dan mengakibatkan kerugian perusahaan, maka karyawan tersebut akan diberi sanksi yang tegas sebagai konsekuensinya seperti pemberhentian dari pekerjaannya. Sebagai bentuk motivasi agar karyawannya semangat dan giat dalam bekerja, Ibu S akan memberikan reward berupa bonus, kenaikan gaji dan THR sesuai dengan kemampuan, kinerja, posisi dan lamanya karyawan tersebut bekerja di perusahaan. Hal ini bertujuan agar seluruh karyawan terdorong untuk memberikan pekerjaan yang lebih daripada yang diharapkan perusahaan.

Meskipun sebagai seorang pemimpin Ibu S harus memiliki sifat-sifat yang lebih dari orang-orang yang dipimpinnya, namun tetap saja Ibu $\mathrm{S}$ memiliki sisi negatif dari kepemimpinannya seperti mudah berubah pikiran dalam pembuatan peraturan baru, kurang percaya diri dalam pengambilan 
keputusan, kurang ketat dalam monitoring kerja karyawannya, dan memberikan kepercayaan yang lebih pada karyawan lama dibanding dengan karyawan lainnya.

\section{Sistem Pengendalian Manajemen di PT. X}

Sistem pengendalian manajemen yang diterapkan berguna untuk mengendalikan sumber daya manusia yang memiliki perbedaan latar belakang budaya, agar tindakan yang mereka lakukan sejalan dengan tujuan yang diharapkan perusahaan. Demikian dengan PT. X juga memiliki berbagai pengendalian yang diterapkan pada para karyawannya baik secara formal yang meliputi pengendalian proses dan pengendalian hasil, maupun informal melalui pengendalian budaya.

\section{a. Pengendalian Budaya}

Metode yang digunakan PT. X dalam pengendalian budaya meliputi seleksi dan pelatihan karyawan baru, disiplin kerja karyawan, interaksi sosial. Budaya yang ada di PT. X dipengaruhi Ibu S yang menanamkan nilai-nilai dalam perusahaan seperti nilai kedisiplin, kerapian dan kerajinan, kepedulian, kebersamaan, dan kesabaran.

Hal-hal yang dilakukan Ibu S sebagai pemimpin antara lain saat diluar jam kerja, Ibu $\mathrm{S}$ berbincang-bincang dengan karyawannya sambil bercanda tawa menanyakan kabar karyawannya baik tentang pekerjaannya maupun masalah keluarga. Menunjukkan sikap saling pengertian akan menumbuhkan ikatan emosional antara pemimpin dengan karyawan, sehingga karyawan merasa diperhatikan dan dihargai sebagai bagian dari keluarga besar perusahaan.

PT. X melakukan perekrutan karyawan baru lebih banyak berdasarkan referensi dari teman dan keluarga. Dalam PT. $\mathrm{X}$ ini, tidak ada training secara khusus yang diberikan bagi karyawan baru. Atasan akan secara langsung mengajari dan menjelaskan gambaran kerja, kemudian karyawan baru akan langsung memulai kerja. Selanjutnya atasan akan memberikan 
kepercayaan kepada karyawan lama dalam memberikan bimbingan kepada karyawan baru untuk memahami tujuan setiap pekerjaannya.

Kedisiplinan yang ada di PT. X terkait dengan peraturan jam dan pulang kerja serta kehadiran karyawan di kantor. Semua karyawan di PT. X ini harus displin dan tepat waktu saat datang maupun pulang kerja. Maximal keterlambatan hanya 5 menit, sehingga jika lebih dari itu akan ada pemotongan bonus kerajinan terhadap karyawan yang bersangkutan. Jika karyawan tidak hadir tanpa pemberitahuan akan diberi sanksi pemotongan gaji.

Ibu S juga berusaha meningkatkan interaksi sosial antara karyawan dengan mengadakan acara-acara informal diluar jam kerja. Misalnya seperti wisata bersama ke tempat yang dipilih berdasarkan voting karyawan setiap setahun sekali. Selain itu juga diadakan ramah tamah atas perayaan ulang tahun PT. X dan perayaan ulang tahun atasan. Melalui acara-acara tersebut maka hubungan antar karyawan maupun dengan pemimpin akan semakin baik, sehingga mereka dapat kompak bekerja sama dalam mencapai tujuan perusahaan. Keakraban yang tercipta antara pemimpin dan karyawan akan memberi pengaruh baik pada perkembangan perusahaan serta akan mendukung pembentukan pengendalian budaya dalam menciptakan budaya organisasi yang baik di PT. X.

\section{b. Pengendalian Proses}

Pengendalian proses di PT. X dilakukan melalui keterlibatan karyawan dalam pengambilan keputusan, pertanggungjawaban pelaksanaan kerja, dan adanya SOP untuk dalam memulai pembangunan proyek perumahan.

Setiap karyawan yang ada di PT. X tidak memiliki wewenang dalam pengambilan keputusan besar dalam perusahaan. Partisipasi mereka hanya sebatas dalam memberikan masukan-masukan yang bertujuan membangun kemajuan perusahaan, selebihnya keputusan ada ditangan pemimpin dan keputusan yang diambil tetap mempertimbangkan kepentingan karyawan. 
Dalam menjalankan pekerjaannya, semua karyawan akan dinilai kinerjanya berdasarkan hasil kerjanya dan ketepatan dalam menjalankan tugas dan tanggung jawabnya sesuai yang telah ditetapkan serta berdasarkan deadline tugas yang diberikan sebelumnya. Karyawan berprestasi dan yang telah lama bekerja di PT. X akan mendapat reward berupa kenaikan gaji dan bonus jika berhasil mencapai target. Jika salah satu divisi memiliki kinerja yang menurun, direktur utama akan memanggil kepala divisi yang bersangkutan dan menegur agar mereka bekerja lebih baik lagi dalam mencapai target yang telah ditetapkan.

Perusahaan menerapkan standard operating procedures agar semua karyawan dapat bekerja dengan lebih terstruktur serta mendorong agar dalam beraktifitas mereka dapat patuh pada perusahaan. Melalui standard operating procedures semua karyawan dapat bekerja secara efisien dan efektif karena setiap karyawan mengetahui apa yang menjadi tugas dan tanggung jawabnya masing-masing.

\section{c. Pengendalian hasil}

Pengendalian hasil di PT. X lebih kepada efisiensi proyek dan produktifitas penjualan. Dalam pengerjaan satu rumah akan disesuaikan dengan cicilan user yang bertujuan agar perusahaan tidak mengeluarkan biaya pemeliharaan, jika pembangunan rumah selesai lebih cepat dari cicilan user, sehingga untuk itu Ibu S mendorong divisi administrasi yang bertanggung jawab untuk menagih pembayaran user untuk bekerja lebih efektif dalam menangani user agar tepat waktu dalam pembayaran. Untuk melakukan efisiensi agar dalam sebuah proyek tidak terjadi pembengkakkan biaya, perusahaan akan melakukan pengurangan atau memperkecil biayabiaya yang dirasa tidak diperlukan.

Untuk meningkatkan jumlah unit terjual agar mencapai target, perusahaan akan mendorong marketing agar mempercepat penjualan rumah. Perusahaan akan memberikan insentif berupa transport dan komisi sebagai imbalan, jika marketing dapat memenuhi target yang ditetapkan perusahaan. 
Selain itu, setiap bulan juga akan diadakan rapat yang membahas mengenai kinerja yang dicapai perusahaan. Jika target yang diharapkan belum berhasil dicapai, perusahaan akan mengubah strateginya atau menambahkan terobosan baru seperti memberikan diskon atau bonus lainnya kepada user yang membeli rumah.

\section{Hubungan Gaya Kepemimpinan dan Sistem Pengendalian Manajemen}

Nilai-nilai budaya keluarga mempengaruhi gaya kepemimpinan Ibu $\mathrm{S}$ dan secara tidak langsung menciptakan lingkungan kerja kondusif yang mendukung terbentuknya budaya baik di perusahaan. Namun dalam mengelola perusahaan, juga dibutuhkan sistem pengendalian manajemen yang sesuai dengan kondisi dalam organisasi. Pemimpin tidak bisa hanya mengandalkan karismanya dalam mengendalikan perusahaan, tapi kepemimpinan itu perlu diwujudkan dalam praktek sistem pengendalian manajemen (Efferin dan Hartono, 2015). Melalui sistem pengendalian manajemen, pemimpin dapat menjalankan fungsi pengendaliannya kepada seluruh anggota organisasi baik anggota keluarga maupun non-keluarga serta sebagai sarana dalam menyalurkan nilai-nilai kepada karyawannya.

\section{a. Hubungan Gaya Kepemimpinan dan Penerapan Pengendalian Budaya}

Hal-hal yang dilakukan Ibu S antara lain saat diluar jam kerja, Ibu S berbincang-bincang dengan karyawannya sambil bercanda tawa menanyakan kabar karyawannya baik tentang pekerjaannya maupun masalah keluarga, mendengarkan keluhan dan saran-saran mereka. Keakraban yang tercipta antara pemimpin dan karyawan akan memberi pengaruh baik pada perkembangan perusahaan, serta akan mendukung pembentukan pengendalian budaya dalam menciptakan budaya organisasi yang baik di PT. X. Sesuai dengan pengaruh dari kepemimpinan transformasional, Ibu S mendrorong karyawannya bekerja dengan mandiri, dia memberikan kepercayaan pada karyawannya untuk mengatasi masalah yang ada di pekerjaannya, misal masalah pembatalan rumah oleh user, 
maka karyawan dapat langsung bertindak sesuai dengan memo internal perusahaan tanpa menunggu perintah Ibu S. Hal ini menjadikan karyawan bisa bertanggung jawab terhadap pekerjaanya dan memahami tujuan dari setiap pekerjaannya. Hal ini sependapat dengan Gao et al (2011), yang mengatakan dengan memimpin secara transformasional, karyawan akan lebih terdorong berkomitmen tinggi terhadap nilai perusahaan keluarga dan merasa lebih menyatu dengan pekerjaan mereka melalui komitmen tinggi yang dimiliki untuk tetap berada dalam perusahaan tempat mereka bekerja.

Sebagai pemimpin, Ibu S akan menjelaskan mengenai gambaran kerja kepada karyawan sebelum mereka memulai pekerjaan, setelah itu karyawan tersebut dapat langsung memulai kerja, karena Ibu S selalu membiasakan semua karyawannya untuk mandiri dalam bekerja dan bisa bekerja sama dengan karyawannya lainnya. Selain itu Ibu S juga menerapkan peraturan perusahaan dengan disiplin, Ibu S akan menegur secara pribadi karyawan yang lalai dan memberikan sanksi tegas sesuai dengan tingkat kesalahan.

Interaksi sosial dibangun melalui acara-acara informal yang diadakan perusahaan seperti wisata bersama dan ramah tamah yang bertujuan agar hubungan baik antara pemimpin dan karyawan dapat terjalin baik, sehingga mereka akan lebih kompak dalam bekerjasama mencapai tujuan perusahaan. Acara-acara informal yang diadakan juga menjadi salah satu cara bagi pemimpin untuk menanamkan nilai-nilai budaya yang baik. Selain itu, hal ini akan mendorong terbentuknya hubungan harmonis antar karyawan, karena melalui acara-acara tersebut setiap karyawan memiliki kesempatan untuk mengenal dan akrab satu dengan yang lainnya, sehingga dapat menciptakan adanya budaya yang baik dan kuat, dimana mereka dapat saling membantu dan mengingatkan satu sama lain jika salah satu karyawan melakukan hal yang menyimpang. Hal ini sesuai dengan Efferin dan Soeherman (2010), budaya yang tercipta akan menjadi pengendali perilaku anggota organisasinya yang akan menghasilkan pengendalian informal dalam organisasi. 


\section{b. Hubungan Gaya Kepemimpinan dan Penerapan Pengendalian Proses}

Ibu S terbuka dengan setiap saran dan kritik karyawan, bahkan setiap masukan dari karyawan menjadi bahan pertimbangan bagi Ibu S dalam mengambil keputusan. Hal ini juga membuat karyawan akan merasa dihargai sebagai bagian dari keluarga besar perusahaan, sehingga mereka juga akan punya rasa memiliki terhadap perusahaan.

Dalam mengelola perusahaannya, Ibu S memberikan arahan dan bimbingan pada karyawan baru yang bekerja dengan menjelaskan gambaran kerja di PT. X agar karyawan tersebut tahu apa saja yang harus dikerjakannya. Selain itu, penghargaan juga diberikan oleh Ibu S seperti kenaikan gaji dan bonus jika karyawan berhasil mencapai target, liburan bersama pada saat hari raya idul fitri dan THR yang besarnya disesuaikan dengan masa kerja karyawan di PT. X. Hal ini sependapat dengan Indermun (2013), yang mengatakan bahwa pemimpin dalam bisnis keluarga harus memahami bahwa memberikan penghargaan membuat pekerja bersemangat dan produktif, karena jika menggunakan ancaman, maka karyawan akan berbalik melawan orgnisasi. Selain itu, memberikan teguran dan peringatan akan dilakukan Ibu S, jika ada karyawan yang melakukan kesalahan. Hal ini bertujuan agar karyawan menyadari kesalahannya dan tidak mengulangi kesalahan yang sama.

Sebagai seorang pemimpin, Ibu S mengarahkan setiap karyawannya untuk bisa saling bekerja sama dalam mencapai target penjualan rumah. melalui penerapan standard operating procedures, maka karyawan dapat bekerja secara terstruktur serta mendorong agar dalam beraktifitas mereka dapat patuh pada perusahaan. Sebelum memulai suatu proyek, Ibu S juga membuat perencanaan dan pertimbangan terkait dengan bagaimana supaya perumahan yang akan dibangun bisa bersaing dengan kompetitor lain dengan melakukan perbandingan mulai dari desain, spesifikasi, fasilitas dan harga jual serta pemilihan lokasi yang strategis dan bagaimana terkait dengan ijin-ijin yang diperlukan. Terkait survey lokasi dan membuat 
siteplan (menentukan penamaan blok dan jumlah unit) Ibu S memberikan tanggung jawab tersebut pada suaminya Bapak S dan Bapak T (kakak Bapak S).

\section{c. Hubungan Gaya Kepemimpinan dan Penerapan Pengendalian Hasil}

Untuk meningkatkan efisiensi proyek Ibu S mengarahkan mereka untuk bekerja bersama sesuai dengan tugas dan tanggung jawab masing-masing agar aktivitas perusahaan bisa berjalan lancar. Hal-hal yang dilakukan Ibu S misal mendorong divisi administrasi untuk bisa lebih efektif dalam bekerja terutama dalam melakukan penagihan pembayaran pada user agar user bisa tepat waktu dalam melunasi pembayarannya.

Untuk meningkatkan jumlah unit terjual agar mencapai target, Ibu $\mathrm{S}$ juga memberikan insentif sesuai dengan target yang telah ditetapkan berupa bonus pada marketing dan karyawan lain yang bertujuan agar tidak hanya marketing yang akan lebih giat bekerja, namun seluruh karyawan juga akan termotivasi untuk bekerja dengan sebaik mungkin mempercepat proses penjualan jika ingin mendapat reward dari perusahaan. Ibu S juga mengadakan rapat setiap bulannya untuk meninjau sejauh mana keberhasilan perusahaan dalam mencapai targetnya. Hal ini bertujuan menentukan apa yang harus perusahaan lakukan selanjutnya, misal jika target yang diharapkan belum tercapai, Ibu $\mathrm{S}$ akan membuat sebuah terobosan baru yang berbeda dengan kompetitor lain dan strategi baru seperti memberi diskon atau bonus lain kepada user yang membeli rumah.

\section{Hubungan Gaya Kepemimpinan dan Sistem Pengendalian Manajemen terhadap Budaya yang terbentuk di PT. X}

Gaya kepemimpinan dan sistem pengendalian yang diterapkan akan berbeda dengan organisasi lain dan berpengaruh pada budaya organisasi. Terbentuknya budaya organisasi dipengaruhi oleh bagaimana cara pemimpin dalam memotivasi dan menginspirasi karyawannya agar bisa bertindak sesuai dengan yang diharapkan. Jika seluruh anggota organisasi bisa saling 
memberikan motivasi dan bekerjasama dengan baik, maka otomatis akan membangun pengendalian budaya yang kuat dalam membentuk budaya organisasi yang baik. Dimana, budaya yang terus dipelihara menjadi sangat sulit untuk ditiru dan sekaligus menjadi sumber keuntungan strategis dalam rangka bersaing secara efektif (Denison, 2004). Oleh karena itu, keberhasilan organisasi dalam mencapai tujuannya cenderung dipengaruhi oleh keberhasilan dalam menjaga dan menjalankan nilai-nilai utama yang tercermin dalam budaya organisasi. Yang mana budaya organisasi tersebut akan mendasari perilaku karyawan dalam bekerja yang akan mengahasilkan kinerja tertentu.

\section{Komitmen dan saling bekerja sama}

Pemimpin menjalin hubungan dekat dengan karyawan melalui pendekatan pribadi, sehingga pemimpin dapat mengetahui apa saja kesulitan yang selama ini dihadapi karyawan baik dalam pekerjaan maupun dikeluarganya. Keakraban yang tercipta antara pemimpin dan karyawan akan menumbuhkan ikatan emosional diantara mereka yang mendukung pembentukan pengendalian budaya dalam menciptakan budaya organisasi yang baik di PT. X. Selain itu, melalui acara-acara informal yang diadakan PT. X seperti wisata bersama akan memudahkan pemimpin untuk menanamkan nilai-nilai budaya yang baik kepada seluruh anggota organisasi dan setiap karyawan akan bisa saling mengenal dan akrab satu sama lain, sehingga muncul rasa solidaritas dan toleran antar karyawan. Melalui berbagi nilai-nilai yang sama seperti kesetiaan dan komitmen, bekerja sebagai tim dan memperhatikan kepuasan karyawan akan mengembangkan klan budaya dan mencapai kinerja yang lebih tinggi (Durendez, 2011).

\section{Kemandirian dan disiplin dalam bekerja}

Pemimpin hanya menjelaskan gambaran kerja dan apa saja peraturan di perusahaan kepada setiap karyawan baru, selanjutnya karyawan tersebut langsung memulai bekerja dengan tujuan agar karyawan cepat menguasai 
pekerjaannya dengan sendirinya dan bisa bekerja secara mandiri dengan mengikuti ketentuan yang terdapat dimemo internal perusahaan.

Adanya ikatan emosional yang tercipta baik antar karyawan maupun dengan pemimpin mendorong terciptanya mutual monitoring, sehingga karyawan akan merasa tidak enak dengan pemimpin jika berperilaku tidak sesuai dengan budaya organisasi yang ada. Selain itu, jarang karyawan melakukan hal yang menyimpang dari peraturan, karena adanya mutual monitoring antar karyawan berupa tekanan sosial, sehingga hal ini akan membuat mereka untuk berpikir matang sebelum bertindak dan sebisa mungkin bekerja sesuai dengan peraturan perusahaan serta tidak sembarangan dalam melakukan sesuatu yang merugikan perusahaan. Hal ini sesuai dengan Efferin dan Soeherman (2010), budaya yang tercipta akan menjadi pengendali perilaku anggota organisasinya yang akan menghasilkan pengendalian informal dalam organisasi.

\section{Keterbukaan dalam hubungan kerja}

Keterbukaan ini dibangun dengan pemimpin yang menerima dan menghargai setiap tanggapan dan pendapat karyawan terhadap keputusan perusahaan dan kemajuan perusahaan di masa depan. Melalui hal tersebut mereka menjadi sadar bahwa mereka juga bagian dari perusahaan sehingga mereka akan bertindak selayaknya memiliki perusahaan dengan selalu berpartisipasi memberikan tenaga dan waktunya untuk memajukan perusahaan karena menganggap bahwa kemajuan yang dicapai perusahaan juga merupakan hasil kerjanya.

\section{Bertanggung jawab dalam bekerja}

Sebagai bentuk motivasi pemimpin juga memberikan imbalan yang sesuai seperti pemberian bonus jika berhasil mencapai target. Hal ini bertujuan agar mereka bisa bekerja dengan lebih bertanggung jawab dan lebih giat dalam mencapai target yang telah ditetapkan, karena mereka menganggap bahwa pekerjaan mereka tidak sia-sia. Hubungan yang dekat antara pemimpin dan karyawan menjadikan tidak adanya batasan hubungan 
diantara mereka, sehingga akan membentuk pengendalian budaya yang efektif, dimana karyawan akan sungkan jika mereka tidak bekerja sesuai yang diharapkan pemimpin. Hal ini akan mendorong mereka untuk bekerja lebih keras dan bertanggung jawab atas pekerjaan yang mereka lakukan.

\section{Berorientasi pada proses}

Dalam memberikan pengarahan, Ibu S selalu mengkomunikasikan dengan jelas dan tepat, sehingga mereka menjadi paham tujuan dari setiap pekerjaan mereka. Sebelum memberikan tugas khusus, Ibu S akan mempertimbangkan kemampuan karyawan tersebut agar pekerjaan yang diberikan bisa dipahami dan diselesaikan dengan baik oleh karyawan tersebut. Seluruh karyawan juga selalu ditekankan untuk mengerjakan pekerjaan dengan rapi dan teliti yang bertujuan, agar karyawan dapat bekerja tidak hanya berdasarkan deadline semata, namun mereka juga dituntut untuk mengahasilkan pekerjaan dengan hasil yang baik dan tepat waktu.

\section{Kesimpulan}

Budaya organisasi berperan dalam mengarahkan keberlangsungan perusahaan di masa depan dan untuk itu dibutuhkan adanya peran pemimpin dan sistem pengendalian manajemen untuk membentuk budaya yang baik dan kuat. Nilai-nilai budaya keluarga yang ditanamkan pemimpin yang telah melekat dalam diri karyawan menjadi pengendali perilaku, sehingga secara tidak langsung mereka bertindak sesuai dengan yang diharapkan perusahaan. Selain itu adanya keterbukaan yang ditunjukkan oleh pemimpin dalam membangun hubungan yang baik dengan seluruh karyawannya akan menciptakan suasana kerja kondusif yang kental dengan rasa kekeluargaan dan akan menumbuhkan ikatan emosional yang erat antara pemimpin dan karyawan. Melalui ikatan emosional yang erat maka pengendalian budaya dapat berjalan efektif, sehingga membantu implementasinya budaya yang baik ke seluruh anggota organisasi. 
Jadi kepemimpinan yang baik juga perlu didukung dengan sistem pengendalian manajemen yang sesuai. Kepemimpinan yang baik tidak hanya dapat mendesain sistem pengendalian manajemen yang sesuai dengan kondisi dan tujuan yang ada dalam organisasi tetapi juga berperan besar mempengaruhi aktivitas organisasi dalam memberikan visi dan nilai-nilai bisnis, serta menginspirasi mereka untuk bekerja bersama dalam mencapai tujuan perusahaan. Selain itu, pemimpin juga bertanggung jawab bagaimana budaya tersebut bisa terimplementasi dengan baik ke seluruh bagian organisasi. Oleh karena itu, melalui sistem pengendalian yang disertai nilai-nilai moral dan dijalankan secara konsisten, maka karyawan akan dapat bekerja secara baik, karena seiring dengan berjalannya waktu nilai-nilai tersebut mendasari perilaku karyawan dalam bekerja, sehingga akan menciptakan adanya pengendalian budaya yang efektif dalam mendukung terciptanya budaya yang baik.

\section{DAFTAR PUSTAKA}

Acquaah, Moses, 2013. Management Control System, Business Strategy and Performance: A Comparative Analysis of Family and Non-family Businesses in a Transition Economy in sub-Saharan Africa. Journal of Family Business Strategy.

Aronoff, C.E. and Baskin, O.W. 2011.Effective Leadership in the Family Business. United States: Palgrave Macmillan.

Brice, W.D. 2013. Family firm culture and performance: Specific empirical evidence. International Journal of Academic Research in Accounting, Finance and Management Sciences, Vol. 3, No.1, pp. 05-17

Denison, D., Lief, C., Ward, J.L. 2004. Culture in Family-Owned Enterprises: Recognizing and Leveraging Unique Strengths. Family Business Review (2004) 17:61-70

Dewantoro, Djoko. 2011. Pengaruh Kekuatan Keluarga Terhadap Kinerja Melalui Sistem Pengendalian Manajemen pada Perusahaan Keluarga di Surabaya. Majalah Ekonomi No. 3 Desember 2011: 294-310.

Duh, M., Belak, J., dan Milfelner, B. 2010. Core Values, Culture and Ethical Climate as Constitutional Elements of Ethical Behaviour: Exploring 
Differences Between Family and Non-Family Enterprises. Journal of Business Ethics (2010) 97: 473-489.

Duréndez, Antonio, Madrid-Guijarro, Antonia dan García-Pérez-de-Lema, Domingo. Innovative Culture, Management Control Systems and Performance in Small and Medium-sized Spanish Family Firms.Innovar, 2011, Vol.21(40): 137-153.

Efferin, S. 2010. Triangulasi dalam Penelitian Kualitatif-Interpretif di Bidang Akuntansi: Seni Mengelola Keterbatasan. Prosiding Kolokium dan Seminar Nasional Penerapan Triangulation of Methods dalam Penelitian Ilmu-Ilmu Ekonomi, hal: 1-10. FEB UGM dan Formadegama

Efferin, S. dan Hartono, M. S. 2015.Management Control and Leadership Styles in Family Business.Journal of Accounting \& Organizational Change, Vol. 11, No. 1, 2015, pp. 130-159.

Efferin, S. dan Soeherman, B. 2010.Seni Perang Sun Zi dan Sistem Pengendalian Manajemen: Filosofi dan Aplikasi. Jakarta: PT. Elex Media Komputindo.

Gao, Fei Yi, Bai, Shanshan, Bai dan Shi, Kan. 2011. T he Effects of Transformational Leadership in Chinese Family Business How Should Family Business Lead Their Family Employees?.International Journal of Trade, Economics and Finance, Vol. 2, No. 3, June 2011, pp. 218-224.

Giritli, H., Oney-Yazıc1, E., Topcu-Oraz, G., Acar, E., 2013. T he Interplay Between Leadership and Organizational Culture in the Turkish Construction Sector. International Journal of Project Management, 31, 228-238.

Indermun, Miss Vartikka. 2013. Family-owned Business: An Assesment of the Various Leadership Styles and its Influence on Management Decisionmaking. Singaporean Journal of Business Economics, and Management Studies, Vol. 2, No. 3, pp. 63-72.

Julias, Ferdi. 2015. 8 dari 10 Perusahaan Keluarga di Indonesia sudah Memiliki Rencana Suksesi. http://swa.co.id/business-research/8-dari-10perusahaan-keluarga-di-indonesia-sudah-memiliki-rencana-suksesi (diakses 13 Juni 2015)

Kotey, Bernice. 2005. Are performance differences between family and nonfamily SMEs uniform across all firm sizes?.International Journal of Entrepreneurial Behaviour \& Research, Vol. 11, No. 6, pp. 394-421

Lavinda dan M. Surya. 2014. Perilaku Bisnis Keluarga Indonesia (II): Niat Menjadi Lebih Profesional. http://koran.bisnis.com/read/20141223/250/385486/readers-choice- 
perilaku-bisnis-keluarga-indonesia-ii-niat-menjadi-lebih-profesional (diakses 13 Juni 2015)

Merchant, K.A, and W. A. Van der Stede. 2007. Management Control System: Performance Measurement, Evaluation and Incentives, $2^{\text {nd }}$ edition. Prentice Hall: UK.

Mussolino, D. dan Calabro, C. 2014. Paternalistic Leadership in Family Firms: Types and Implications for Intergenerational Succession. Journal of Family Business Strategy 5 (2014) 197-210.

Neuman, W.L. 2011. Social Research Methods: Qualitative and Quantitative Approaches, 7th ed. Boston, USA: Allyn \& Bacon.

Nicholson, N. dan Björnberg, Å. 2005.Family Business Leadership Inquiry. London: Institute for Family Business (UK).

Schein, Edgar H. 2010. Organizational Culture and Leadership, $4^{\text {th }}$ edition. San Francisco: Jossey-Bass, Inc.

Supriadi, Agus. 2014. Survey PwC: 95 Persen Perusahaan Indonesia Adalah Bisnis Keluarga. http:/www.cnnindonesia.com/ekonomi/20141202100356-9215176/pwc-95-persen-perusahaan-indonesia-adalah-bisnis-keluarga/ (diakses 13 Juni 2015)

Vilalonga, B., and Amit. R. 2006. H ow do family ownership, control and management effect firm value?.Journal of Financial Econometrics, 80, pp. 385-417.

Yukl, G. 2010. Leadership in Organizations Seventh Edition. Prentice Hall: New Jersey. 